Journal of Engineering and Applied Sciences 14 (Special Issue 3): 5993-6001, 2019

ISSN: 1816-949X

(C) Medwell Journals, 2019

\title{
Study of the Physical-Chemical Factors and Identification Algae of Groundwater in Dhi-Qar Province, Southern Iraq
}

\author{
Ahmed Al-Ashoor, Bushra Ali Ghyadh and Zainab Mohsen Ibrahim \\ Department of Biology, College of Science, University of Thi-Qar, IQ-64001 Al-Nasiriyah, Iraq, \\ shakerahamed@yahoo.com
}

\begin{abstract}
This study aimed to measure certain physical and chemical factors and trace elements in order to measure the degree of contamination of the groundwater of Al-Nasiriyah city Southern Iraq. Four sampling campaigns (from Autumn 2017 to the Summer of 2018) for physico-chemical analyses and identification algae have been carried out. This study, therefore, concerned 9 wells distributed in 4 districts located in city of Thi-Qar by chosen 13 variables of were selected from water quality variables that have a greater impact on the quality of the studied water and determine its validity for the different uses mentioned by finding the water quality index WHO values; air temperature, water temperature, $\mathrm{pH}$ and dissolved oxygen, turbidity, salinity, nitrate, orthophosphate, silica, iron, zinc, copper and manganese. There was no significant difference between the physico-chemical characteristics of studies well. Concerning algae taxa has been classified in this study. Diatom was the most dominant algae, followed by Chlorophyta and Cyanophyta.
\end{abstract}

Key words: Ground water, trace elements, algae, pollution, wells, Cyanophyta

\section{INTRODUCTION}

The pollution is an important problem in modern societies and the presence of pollutants in water resources, especially the fresh water, makes it a serious and specific problem for growth and life of organisms.

Groundwater is considered as an economical natural resource for drinking water supplies in both urban and rural environments. It is the largest source of available natural liquid fresh water in the planet, about $8-10$ million $/ \mathrm{km}^{3}$ or between 98 and $99 \%$ of the total. It is a strategic water source for human activities. In addition that they often represent large volumes, they generally offer better quality water than surface water. These waters constitute $23 \%$ of the world's freshwater resources (Graham and Wilcox, 2000; Hadi, 1981) which must be preserved and protected from all kinds of pollution. Indeed, the natural levels of pollutants in the water are generally very low but their concentrations increase with human activity such as agriculture (nitrogen fertilizers), industry (effluents released into the receiving environment without any prior treatment), domestic effluents, landfill leachate public. This increase is the main cause of groundwater quality degradation and mainly more vulnerable groundwater.

The Southern Region of Iraq is considered one of the main groundwater-dependent areas classified in previous studies as suitable for agriculture but the steady expansion of agriculture and increased groundwater consumption have led to a decline in water levels (Hassoune et al., 2006; Haddad, 1977). Recent studies have shown a general trend towards a decrease in groundwater reservoirs due to the type of irrigation used and an increase in the number of wells operated in the region, this leads to the removal of large quantities of water reservoirs and thus increases the depth of groundwater and thus, the deterioration of groundwater quality due to the rise of salt water (Celekli et al., 2007).

Intensive cultivation of agricultural land in irrigated areas, public landfills producing a lot of nitrogen-rich leachate on the one hand and the creation of industrial zones on the other have led in recent years to the emergence of the problem of pollution of groundwater resources by nitrates. As a result, concerns about these substances as pollutants increased, not only because of the economic losses to the farmer or the health consequences of the population but also because of the complexity of the problem, given that the population in rural areas is partly are supplied with drinking water from existing wells (Hadi, 1981; Hassoune et al., 2006).

In addition, heavy metals in soils exist in several fractions of the phase solid which can be measured by dissolution selective sequential. The human activities such as effluents industrial and municipal governments then increased the heavy metal flows in groundwater and surface (Gove et al., 2001). Today, the poor management

Corresponding Author: Ahmed Al-Ashoor, Department of Biology, College of Science, University of Thi-Qar, 
of industrial sites has the following objectives consequences of public health problems and land use planning. The many craft industry units in particular the dyeing workshops located on the protective perimeters of the field of view the districts of Thi-Qar are potential points of pollution.

While, soil absorbs and filters many contaminants, smaller particles such as microorganisms, algae, bacteria and viruses can be transported through cracks in rock or permeable soils and then reach the aquifer. This is why thin layers of soil and high groundwater contribute to the vulnerability of groundwater. Fractured soils (rock, sandstone) also promote the rapid movement of water through the soil and consequently, groundwater contamination. In these cases, it may be difficult to identify the source of the pollution accurately, since, it may be located miles from the contaminated wells. Other factors can contribute to the movement of microorganisms to groundwater. Poorly constructed wells (poor design, lack of casing, cracks in the structure, etc.) will allow direct intrusion of contaminants (USEPA., 2002).

Domestic and industrial wastewater which is highly contaminated with heavy metals is discharged without treatment into sumps towards the surface aquifer. The objective of this research is to determine the concentrations of heavy metals in the surface aquifer that is the water supply source for the populations who live on these wells in Thi-Qar city (Southern Iraq).

\section{MATERIALS AND METHODS}

Sample locations: The map in Fig. 1 presents, the study area. Four districts in Dhi-Qar Province were selected to collect water samples from their wells.

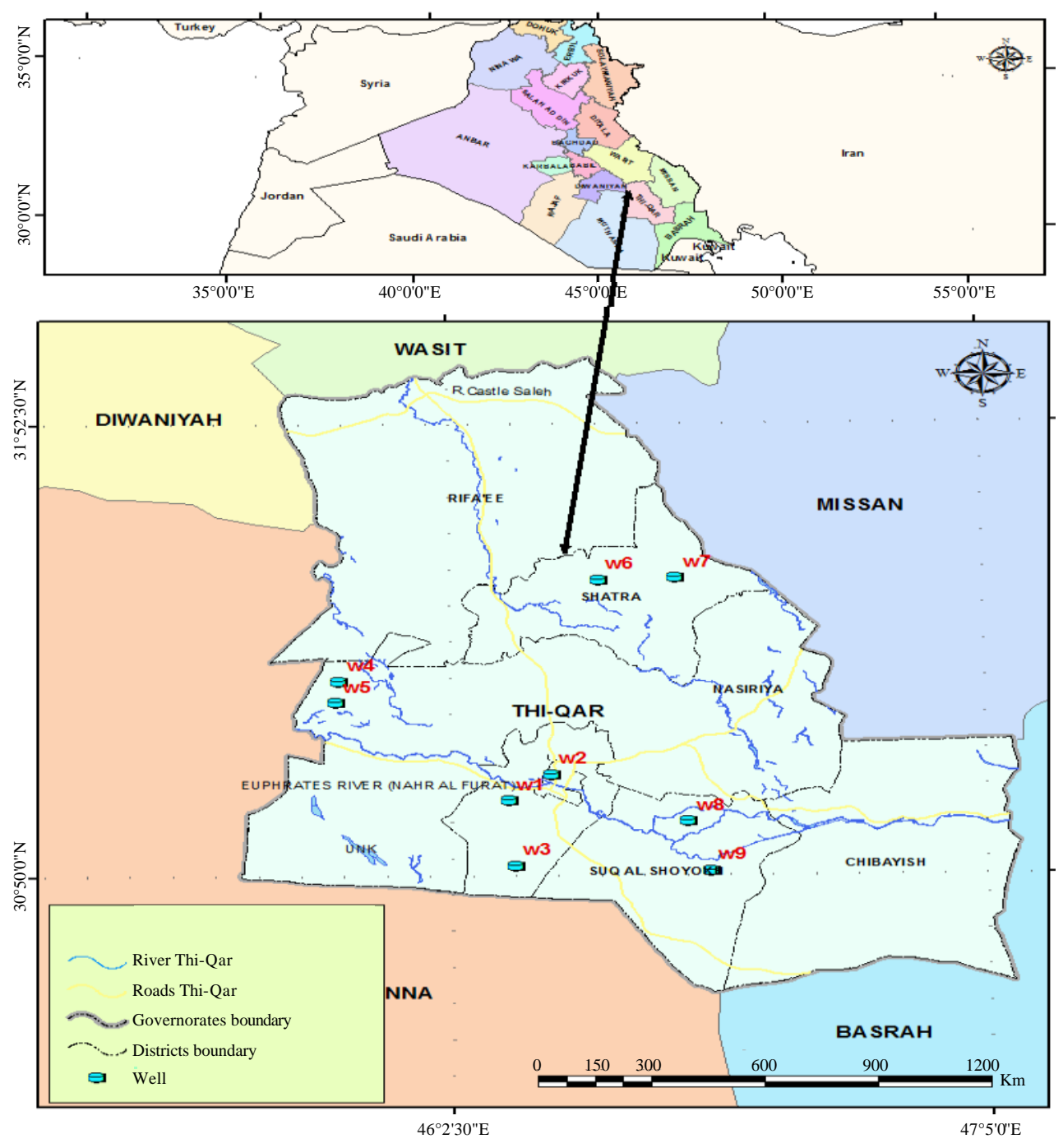

Fig. 1: Map of Thi-Qar Province indicated the location of the wells studied 
To study the impact of pollution on water quality in the groundwater of Thi-Qar city, four sampling campaigns (from Autumn 2017 to the Summer of 2018) for physico-chemical analysis have been carried out. Samples were collected until they overflowed into polyethylene bottles $(3 \times 500 \mathrm{~mL})$, rinsed with distilled water, water was pumped from the well for $20 \mathrm{~min}$ to ensure that the sample represented the quality of the groundwater that fed the well then with the water to be sampled and capped. Certain hydrochemical parameters were measured in the field during sample collection prior to filtering and acidification, including water wells temperature and air temperature, $\mathrm{pH}$, dissolved oxygen, salinity, turbidity, nitrate, orthophosphate and silica. These were measured using a YSI 85 temperature, an Mi 170 Hanna $\mathrm{pH}$ meter, a Hanna dissolved oxygen meter, EC-meter Hanna EC-215, turbidity meter, method (Wood at el., 1967), method (APHA., 2005a, b) and method (Parsons el al., 1984).

For the analysis of heavy metals, a few drops of nitric acid were added to the sample to ensure preservation in an acid medium and immediately put in a cooler. Samples for the phytoplankton community study were collected using a $1 \mathrm{~L}$ closing bottle for samples collected from all wells. The algae samples were examined using an optical microscope. algae species identified, according to the following references (Prescott, 1962; Desikachary, 1959; Celekli et al., 2007).

This study, therefore, concerned 9 wells distributed in 4 districts located in city of Thi-Qar. The wells (W6W7) are located in Al-Bathaa area, West of Nasiriyah District. The wells (W6-W7-W3) in the District of Shatrah in North of the province of Thi-Qar, located (W8-W9) in the Northern part of the Askika East of Souk al-Shuyukh District, South of the province. The analysis performed included the following variables: total iron, manganese, copper and zinc. These heavy metals are measured (depending on the method used by APHA. (2005a, b) at the Laboratory of Applied Science of the Faculty of Sciences of Thi-Qar University and the Technical Institute of Al-Shatrah in the Southern Technical University with three replicates per sample by the atomic absorption spectrophotometer. In all the analysis each sample was analyzed twice per analyte and the mean value was used as the final result.

\section{RESULTS AND DISCUSSION}

Figure 2-10 presents the temperature of air, temperature of wells water, $\mathrm{pH}, \mathrm{DO}$, salinity, turbidity, nitrate, orthophosphate and silica of the water from the individual wells collected between Autumn 2017 to the Summer of 2018.

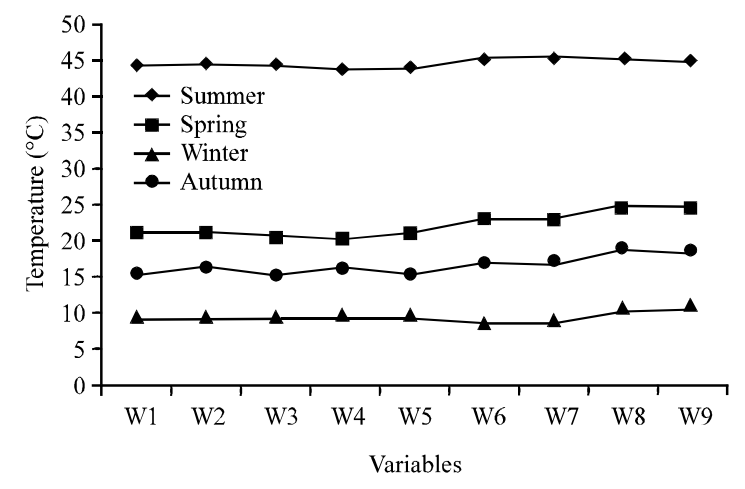

Fig. 2: Seasonal variations to the rates of air temperatures in the wells studied

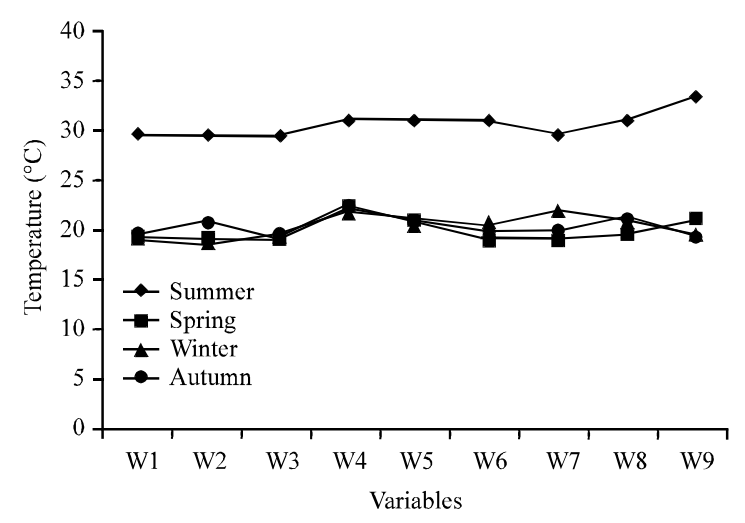

Fig. 3: Seasonal variattion of the rate groundwater temperatures in the wells studied

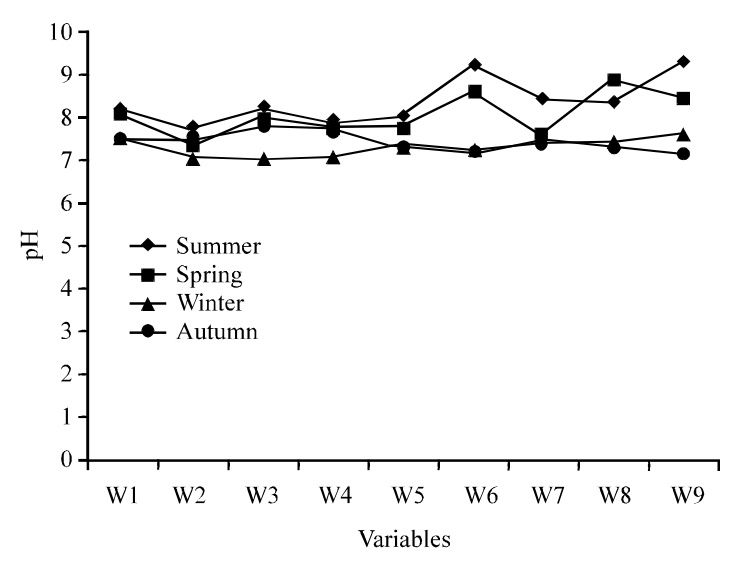

Fig. 4: Seasonal variation of the rate $\mathrm{pH}$ in the wells studied

The average temperature in the wells recorded between 7:00 and 8:00 am is $44.27^{\circ} \mathrm{C}$ in the Summer (Fig. 2). The highest value is $45.3^{\circ} \mathrm{C}$ observed in wells number (9). The results of statistical analysis showed that the 


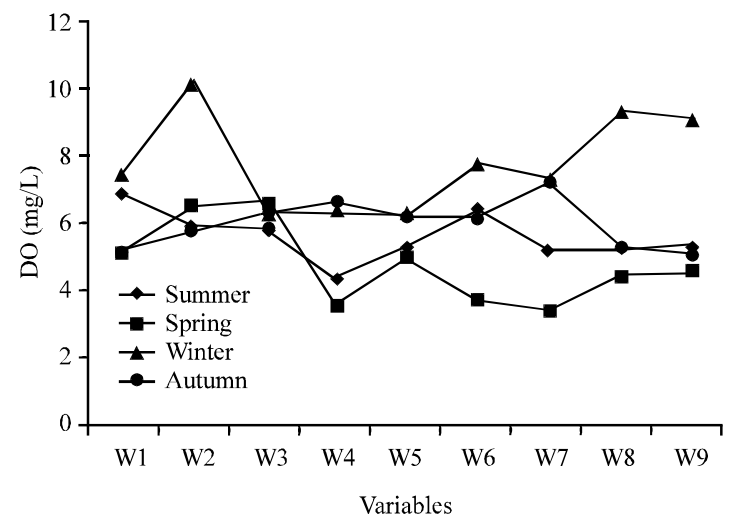

Fig. 5: Seasonal variation of the rate dissolved oxygen in the wells studied

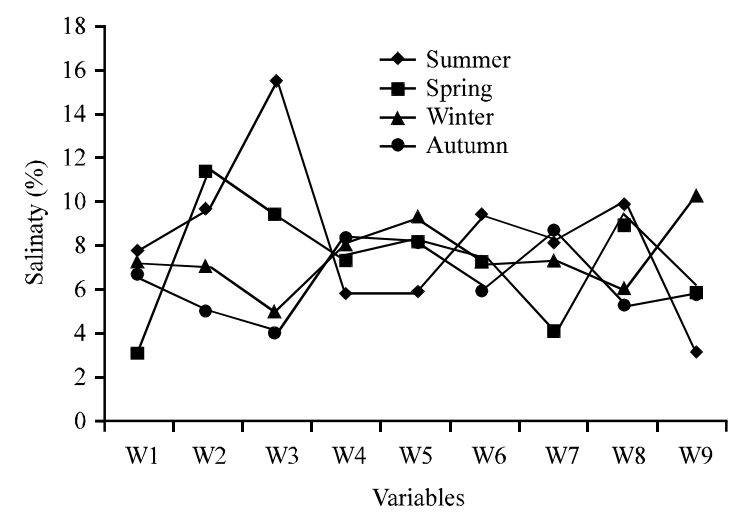

Fig. 6: Seasonal variations of the rate of salinaty in the wells studied

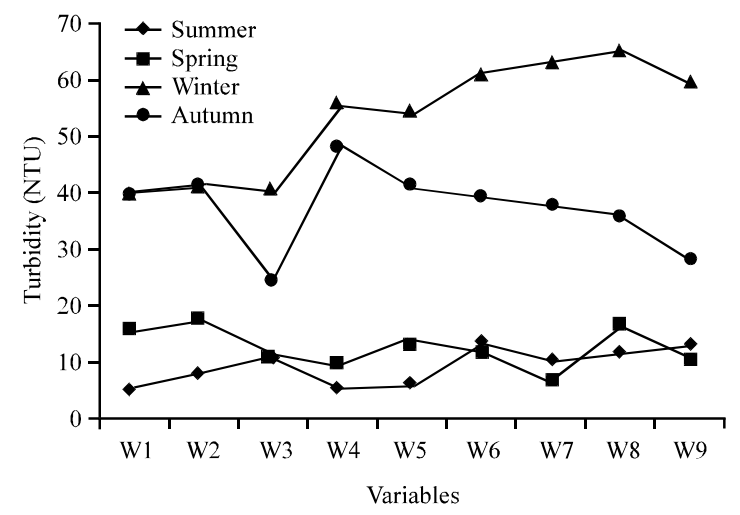

Fig. 7: Seasonal variations of the rate turbidity in the wells studied

temperature of the water in the wells studied were not significantly different at $p \leq 0.05$. During this study, our results showed normal seasonal variations in temperature profiles in wells water (Fig. 3). The temperature variations

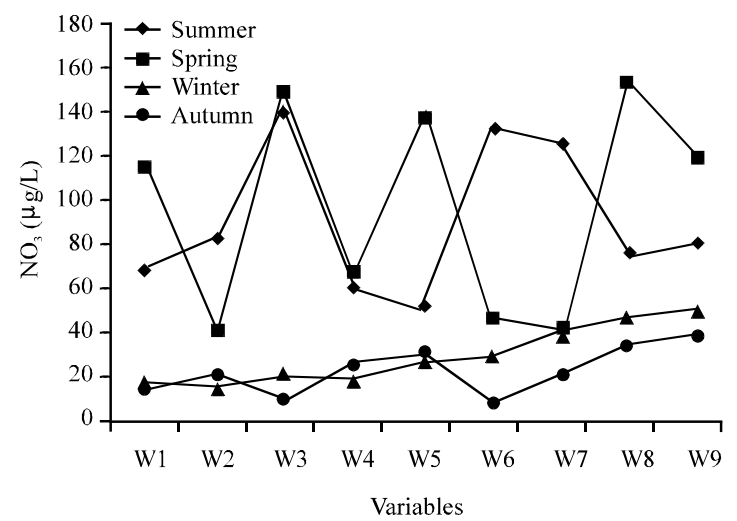

Fig. 8: Seasonal variation of the rate of nitrate in the wells studied

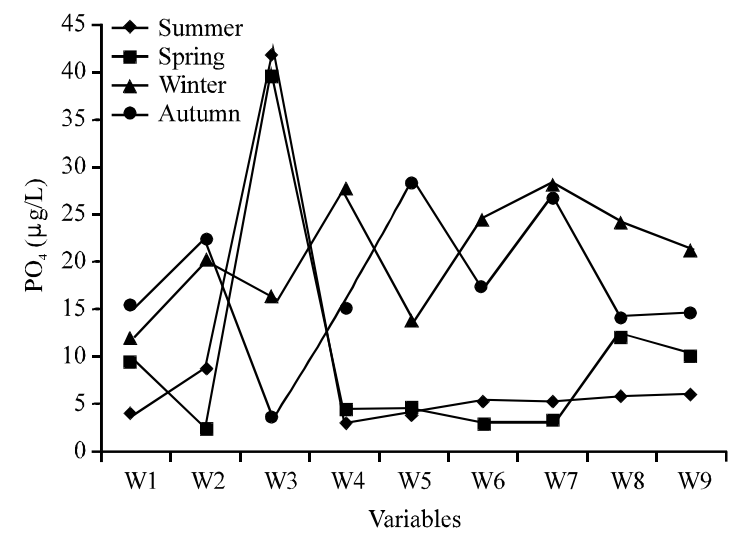

Fig. 9: Seasonal variation of the rate of $\mathrm{PO}_{4}$ in the wells studied

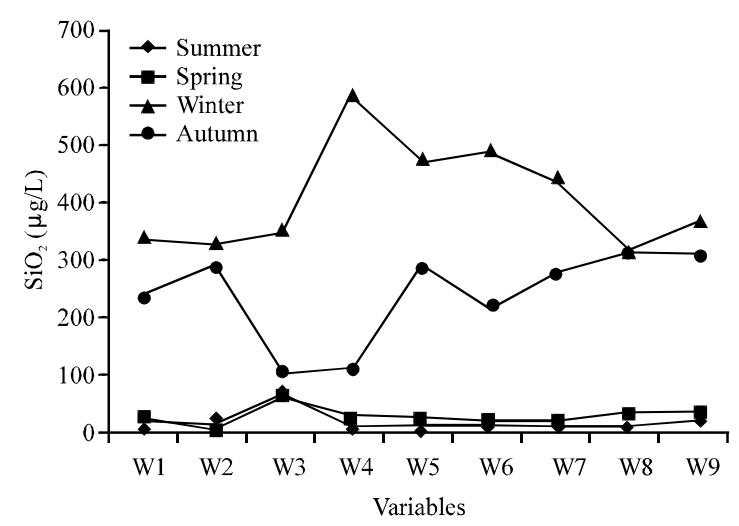

Fig. 10: Seasonal variation of the rate of silica in the wells studied

recorded in the nine wells ranged from 33.5 (well 9 in Summer) to $18.5^{\circ} \mathrm{C}$ (well 2 in Winter). The hydrogen ion $(\mathrm{pH})$ concentration ranged from 7 (in well 3 in Winter) to 


\section{J. Eng. Applied Sci., 14 (Special Issue 3): 5993-6001, 2019}

Table 1: Concentration of the different trace elements (mean \pm SD) at the wells level (Autumn 2017 to the Summer of 2018) Wells

\begin{tabular}{|c|c|c|c|c|c|c|c|c|c|}
\hline \multirow[b]{2}{*}{ Elements (mg/L) } & \\
\hline & W1 & W2 & W3 & W4 & W5 & W6 & W7 & W8 & W9 \\
\hline $\mathrm{Fe}$ & $0.07 \pm 0.07$ & $0.15 \pm 0.05$ & $0.09 \pm 0.09$ & $0.13 \pm 0.05$ & $0.16 \pm 0.05$ & $0.20 \pm 0.16$ & $0.18 \pm 0.08$ & $0.10 \pm 0.05$ & $0.18 \pm 0.06$ \\
\hline $\mathrm{Zn}$ & $0.18 \pm 0.05$ & $0.35 \pm 0.21$ & $0.30 \pm 0.21$ & $0.34 \pm 0.26$ & $0.32 \pm 0.16$ & $0.27 \pm 0.15$ & $0.44 \pm 0.26$ & $0.36 \pm 0.20$ & $0.27 \pm 0.13$ \\
\hline $\mathrm{Cu}$ & $0.13 \pm 0.05$ & $0.15 \pm 0.06$ & $0.13 \pm 0.05$ & $0.10 \pm 0.08$ & $0.15 \pm 0.13$ & $0.16 \pm 0.05$ & $0.13 \pm 0.10$ & $0.10 \pm 0.08$ & $0.10 \pm 0.08$ \\
\hline $\mathrm{Mn}$ & $0.04 \pm 0.024$ & $0.04 \pm 0.021$ & $0.04 \pm 0.03$ & $0.03 \pm 0.014$ & $0.04 \pm 0.024$ & $0.04 \pm 0.016$ & $0.04 \pm 0.021$ & $0.04 \pm 0.015$ & $0.03 \pm 0.023$ \\
\hline
\end{tabular}

-9.3 (well 9 in Summer). During the study periods, all wells had $\mathrm{pH}$ values $>7$ (Fig. 4). The results of the statistical analysis revealed no significant difference at $\mathrm{p} \leq 0.05$ between wells water. There are significant differences between the Spring season compared to the Winter season and the fall season at the same level.

As indicated in the material and methods in this study, DO was measured for the nine wells. The development of this parameter in each well was monitored and reported (Fig. 5). The evolution of DO content for the period between Autumn 2017 to the Summer of 2018 is presented in Fig. 5. The contents varying between 3.4 (well 7 in Spring and 10.2 well 2 in Winter). The results of the statistical analysis revealed no significant difference at $p \leq 0.05$ between wells water. Although, there were significant differences for all seasons except fall vs. Winter at the same level.

From the analysis of Fig. 6, it appears that the average salinity in the sampled wells is 8.28 . This value is almost identical to that recorded in Summer 2017 but the maximum salinity obtained is still 15.5 in the well 3 . The results of the statistical analysis revealed no significant difference at $\mathrm{p} \leq 0.05$ between wells water and there were no significant differences between all seasons for all wells at the same level. The values of silica ranged between $(2.2 \mu \mathrm{g} / \mathrm{L}$ in well 2 and $586 \mu \mathrm{g} / \mathrm{L}$ in well 4$)$. As for turbidity, the average value of $53.11 \mathrm{NTU}$ is greater than that recorded during the previous great Summer season. The highest value of turbidity it was 65 NTU (well 8 in Winter) while the lowest turbidity is recorded in well 1 (5.2 NTU) in Summer. The results of the statistical analysis revealed no significant difference at $\mathrm{p} \leq 0.05$ between wells water. The concentration rate of nitrate (Fig. 8) during 4 seasons was between $(9 \mu \mathrm{g} / \mathrm{L}$ in well 6 and $155 \mu \mathrm{g} / \mathrm{L}$ in well 8$)$. The results of this study indicated that the active phosphates (Fig. 9) were between $(2.3 \mu \mathrm{g} / \mathrm{L}$ in well 2 and $40.3 \mu \mathrm{g} / \mathrm{L}$ in well 3).

From the analysis of this Table 1, it appears that the water from wells is not polluted by iron. The concentration of iron element in all wells during the four seasons. It was $<0.3 \mathrm{ppm}$. The highest concentration of iron is $(0.18 \mathrm{ppm})$ was recorded in well 7 and 9. The highest $\mathrm{Zn}$ concentration values were recorded in well 7 $(0.44 \mathrm{ppm})$ while the concentration value was at least in well 1 where it reached $(0.18 \mathrm{ppm})$. Table 2 shows a larger difference in the distribution of copper in the study area. The value of copper in the well (6) was $(0.16 \mathrm{ppm})$ and the lowest value in the well $(4,8$ and 9$)$ was $(0.10 \mathrm{ppm})$, notes lack of copper concentration and absence of contamination in the study area within the limits allowed by World Health Organization (2011) (2 mg/L). The concentration of $\mathrm{Mn}$ does not exceed ( $2 \mathrm{ppm}$ ) in all wells during all sampling campaigns. The results of the statistical analysis for all trace elements revealed no significant difference at $\mathrm{p} \leq 0.05$ between wells water and there were no significant differences between all seasons for all wells at the same level.

The samples investigated were generally composed by bacteria, algae, cyanobacteria, fungi, mosses and some grazers such as rotifers. We focus this study on algae and cyanobacteria specimens. A total of 15 species of diatoms and 12 species of green algae and 9 cyanobacteria and 1 euglinophyta were identified among the 9 wells (Table 2). Indeed, the mean specific richness for each sample was quite low as we identified an average of 5.2 species per sample, the composition of samples varying between 1 and 11 species. Diatoms were the most abundant $(41 \%)$ whereas green algae were found to be predominant under the colonial form (32\%), Cyanobacteria was $(24 \%)$ while Euglinophyata was $(3 \%)$.

This study has shown a significant variation in air temperature over the seasons, it recorded the highest rates during the long hot Summer and the lowest rates during the short and coolest Winter. This is what we know about the nature of the Iraqi climate, in general, the differences in situation may be due to a different time of sampling (Wetzel, 2001).

The degree of well water temperature is the highest in Summer and the lowest in other seasons, due to the distance from the ground surface and the absence of vulnerability to heat from the air (Kena, 2001).

The $\mathrm{pH}$ value 7 is the optimal level of the freshwater and the water remains usable when it increases or decreases from 4 and the $\mathrm{pH}$ is generally between 9 and 2 for most natural waters. Some factors affect the concentration of the hydrogen element or the $\mathrm{pH}$ degree of the reaction such as precipitation and flooding that dissolve natural pollutants and include soil solubility as well as human activities, agricultural activities, the use of pesticides, various fertilizers, wastewater and plant waste 
Table 2: Distribution of identified algae in the nine wells during the period of the study

\begin{tabular}{|c|c|c|c|c|c|c|c|c|c|}
\hline Phytoplankton & W1 & W2 & W3 & W4 & W5 & W6 & W7 & W8 & w9 \\
\hline \multicolumn{10}{|l|}{ Diatoms } \\
\hline Synedra radians Kutz. & + & + & + & - & - & + & - & + & + \\
\hline S. rumpens & - & + & + & + & - & - & + & + & + \\
\hline Navicula consors A. Schmidt (1874) & - & - & + & + & + & - & + & + & + \\
\hline Cyclotella menghinian keutzing (1930) & + & - & - & - & - & + & - & - & - \\
\hline Cymbella microcephala Grum. & + & + & + & + & + & - & + & - & - \\
\hline Synedra sp. & - & + & + & - & - & - & - & + & - \\
\hline Achnonthes affinis & + & + & - & - & - & - & - & + & + \\
\hline Diatoma vulgare & + & + & + & + & - & + & - & - & - \\
\hline Pinnularia sp. & - & + & - & - & - & + & - & - & - \\
\hline Nitzschia sigmoidea (Ehr.) W.Smith (1853) & + & - & - & + & + & + & - & + & + \\
\hline N. dubia & + & - & - & + & + & + & - & - & - \\
\hline Amphora sp. & + & - & - & - & - & - & + & - & + \\
\hline Baxillaria paxillifer (O. F. Mull.) Hendy (1951) & + & - & - & - & - & + & + & + & + \\
\hline Fragilaria virescens Rafls & + & + & - & - & + & + & + & + & + \\
\hline F. construens & + & + & + & - & + & + & + & + & + \\
\hline \multicolumn{10}{|l|}{ Chlorophyta } \\
\hline Scenedesmus sp. & - & + & - & + & - & - & - & - & - \\
\hline Closterium sp. & - & - & - & - & + & - & - & - & - \\
\hline Chlorella ellipsoidea Gemeck (1907) & + & - & - & - & - & + & - & - & - \\
\hline Eudorina elegans Ehrenberg (1832) & - & - & - & - & - & - & - & + & + \\
\hline Pandorina sp. & - & - & - & - & + & - & - & - & - \\
\hline Cosmarium botrytis Menegh. Ex Ralfs & - & - & + & - & - & - & - & - & - \\
\hline Zygnema sp. & + & - & - & - & - & - & - & - & - \\
\hline Chlorella ellipsoidea Gemeck (1907) & - & + & - & + & - & - & - & - & - \\
\hline Spirogyrasp. & - & + & + & - & - & - & - & - & - \\
\hline Microsporasp. & + & - & - & - & - & - & - & - & - \\
\hline Gloeocapsa sp. & - & - & - & - & + & - & - & - & - \\
\hline Ulothrix zonata (Weber and Mohr) Kuetzing & - & - & - & - & - & - & + & + & - \\
\hline \multicolumn{10}{|l|}{ Cyanophyta } \\
\hline Oscillatoriasp. & - & - & - & - & + & - & - & - & + \\
\hline Rivularia sp. & - & - & - & - & - & - & + & + & - \\
\hline Chroococcus varius & + & - & - & - & - & - & - & - & - \\
\hline Gloeotrichiasp. & - & - & + & - & - & - & - & - & - \\
\hline Calothrix sp. & - & - & + & - & - & - & - & + & - \\
\hline Microsystis aeruoginosa & + & - & + & - & - & - & - & + & - \\
\hline Synechococcus aeroginosus Nageli & - & + & - & - & - & - & - & - & - \\
\hline Lyngbyasp. & - & + & - & - & - & - & - & - & - \\
\hline Spirulinasp. & + & - & + & - & - & + & - & - & - \\
\hline \multicolumn{10}{|l|}{ Euglinopyta } \\
\hline Euglena gracilis Klebs & - & - & - & - & - & - & - & + & + \\
\hline
\end{tabular}

in the region and the value of $\mathrm{pH}$ is also affected by the concentration of compounds carbonates and bicarbonate dissolved in water (Xie et al., 2010).

Dissolved oxygen in ground water depends on its source and temperature as well as on vital processes such as photosynthesis, respiration, decomposition processes in the water column and the amount of rain (Rasolofomanana, 2009). The reason for the elevated levels of dissolved oxygen in some wells during the winter is due to the inverse relationship between temperatures and gas melting and in particular the ability to melt $\mathrm{O}_{2}$ at low temperatures (Leppi et al., 2016). The results of this study showed a high salinity rate in well 3 due to crop irrigation who works to wash the soil adjacent to the surrounding wells and thus, the filtration of this water to groundwater which leads to a high proportion of salts (Xia et al., 2016).

The highest turbidity rate was observed in Winter and in most wells due to increased groundwater turbidity in most wells, the mixing of sludge, sand and mud with the proposed groundwater and interactions with the proposed groundwater Chemistry between rocks and groundwater that occurs in the underground reservoir (Ma et al., 2015). Some economic activities are carried out on the perimeters of the Thi-Qar city and compromise the quality of the resource. These are the activities of market gardening that uses a significant amount of chemical fertilizer and pesticide. Dyeing activities also release significant amounts of wastewater into the soil without any purification. Finally, the absence of a solid waste management system household and biomedical waste leads people to dump these pollutants into wells abandoned domestic waste, thus, contributing to chemical and microbiological pollution of the surface aquifer waters.

In effect, the implementation of the land use plan in the municipality of Thi-Qar did not precede the settlement of the populations. At the end of the subdivision and 
resettlement works, many individual wells are found on public roads. To close them, people dump solid waste of all kinds into them, unconsciously sending waste from the soil surface to the surface aquifer that feeds nearby wells. This behavior explains the high iron levels $(0.2 \mathrm{mg} / \mathrm{L}$ in well 6 when the standard is $0.3 \mathrm{mg} / \mathrm{L})$ (World Health Organization, 2011). Most of these above-standard pollutants were measured in the waters of individual wells located around these abandoned individual wells and transformed into landfills circumstantial. These values are similar to those of Azokpota (2005) who found iron content of $0.8 \mathrm{mg} / \mathrm{L}$ in water wells in the Cotonou districts where dyeing activities are carried out. Indeed, the intensity of groundwater pollution depends on the type of soil and the dose in pollutants (White et al., 1986).

Zinc levels in ground water are low at almost all wells. In well 7 , it is $0.44 \mathrm{mg} / \mathrm{L}$ and increases to $0.18 \mathrm{mg} / \mathrm{L}$ in well 1 when the standard is $3 \mathrm{mg} / \mathrm{L}$ (World Health Organization, 2011), it appears that this site is not chemically polluted by zinc. The role of dyeing activities in zinc supply is remarkable here. The main cause of chemical pollution of water from individual wells is the lack of hygiene and sanitation on the perimeters of the wellfield. However, the water and sanitation problem is not specific to the Thi-Qar city wellfield. It is possible that the lack of zinc concentrations to the light base groundwater in the study area where $\mathrm{pH}$ values between 7 and 9.3.

We note that the lack of copper concentration and pollution in the study area within the permitted limits $2 \mathrm{mg} / \mathrm{L}$ may be caused by some adsorption concentrations of clay minerals used in the composition of sulphide, due to the presence of sulphur in the composition of the region and the conditions of its base water (Fifi et al., 2013). All well water tested contains manganese at variable rates between 0.03 and $0.04 \mathrm{mg} / \mathrm{L}$ when the standard is $0.5 \mathrm{mg} / \mathrm{L}$ (World Health Organization, 2011). This manganese pollution in most well waters is believed to be due to the countless wild garbage dumps in the study area. These results lead us to say that the wastewater management method on the Thi-Qar provenance wellfield contributes to the chemical pollution of the aquifer of this city.

According to Gerba and Haas (1988), the frequency and intensity of water contamination varies over time and according to geography. The populations anarchically settled on the perimeters of these wells wellfield do not have a collective sanitation network. Those who do individual sanitation do so, without complying with current health standards. When the quality of borehole water is closely analyzed, it is found that it is not polluted by heavy metals because it is well protected by impermeable geological layers.

The nitrate is one of the forms of nitrogen in water and is found in organic matter; nitrates enter water from a variety of sources, including rainwater carrying nitrogen-containing compounds from the air, domestic and industrial wastewater contaminated with these compounds and water from agricultural land where nitrogen-containing compounds are used as fertilizer. The high nitrate concentrations in well 3 during Summer and Spring are due to increased agricultural and biological activities as well as the presence of decomposing plant residues that add nitrogenous organic compounds to the environment (Davis and DeWiest, 1966).

The nitrate concentration in the study area is generally low in which there is no groundwater pollution by nitrates because the groundwater in this area is deep and far from surface pollution sources with waste wastewater industrial waste. Phosphate concentration in the wells in the study area is high for several reasons; the most important sources of phosphorus in groundwater systems include overlying soils, dissolution of minerals that contain phosphate in aquifer sediments, agricultural fertilizers, animal waste and septic leaks wastewater systems or infiltration (Fuhrer, 1999).

Silica is one of the most important factors for the growth of phytoplankton it is involved in the structure of the cell wall, especially in diatoms, it is produced by soil degradation, especially containing feldspars, it has a slow cycle by nature compared to other elements because it has entered into the structure of diatoms in a way that is difficult to decompose (Horne and Goldman, 1994). This study recorded the highest values of silica in Autumn and Winter, probably due to heavy precipitation during these seasons which resulted in soil washing and feldspars melting in groundwater. It can be caused by microorganisms that degrade minerals and increase silica concentrations in well water, due to excessive consumption of diatoms in groundwater in the Spring.

The results showed a difference in the presence of algae in water wells during seasons, there was a significant increase in their presence in the Spring and fall in the wells studied. Compared to Summer and Winter. This may be due to the similarity of conditions exposed to temperature wells in the Spring and fall. The percentage of green algae was lower than diatoms in the current study due to the depth of the wells and the lack of light reaching the water; these algae require a high level of light for growth, reproduction and other activities (Graham and Wilcox, 2000). 


\section{CONCLUSION}

This study found that heavy metal concentrations of water from individual wells located on the city of Thi-Qar wellfield varies from one point to another and from one season to the next. These pollutants are for the most part above the standard unlike borehole water which is of good quality because it is well protected by the geological layers. It is urgent to ensure that the easements on the wellfield are respected not to pollute the groundwater that supplies the city of Thi-Qar with drinking water.

\section{ACKNOWLEDGEMENT}

This study was supported by College of Science, University of Thi-Qar, IQ-64001 Al-Nasiriyah, Iraq and is the result of the college's collaboration with the College of Education for Pure Sciences, University of Basrah, Iraq.

\section{REFERENCES}

APHA., 2005a. Standard Methods for the Examination of Water and Wastewater. 21st Edn., American Public Health Association, Washington, DC., USA., ISBN-13: 978-0875530475, Pages: 1200.

APHA., 2005b. Standard Methodsfor the Examination of Water and Wastewater. 21st Edn., American Public Health Association, Washington, USA., Pages: 22621.

Azokpota, V., 2005. [Impact of the use of dyes on the quality of the cottony aqueous environment: Case of the artisanal dyeing of textiles]. DESS/MQUE, UAC/FAST Mem Inc., Madison, Connecticut, (In French)

Celekli, A., O. Obali and O. Kulkoyluoglu, 2007. The phytoplankton community (except Bacillariophyceae) of lake Abant (Bolu, Turkey). Turk. J. Bot., 31: 109-124.

Davis, S.N. and R.J.M. DeWiest, 1966. Hydrogeology. 1st Edn., John Wiley \& Sons Inc., New York, USA., Pages: 128.

Desikachary, T.V., 1959. Cyanophyta. Indian Council of Agricultural Research, New Delhi, India, Pages: 686.

Fifi, U., T. Winiarski and E. Emmanuel, 2013. Assessing the mobility of lead, copper and cadmium in a calcareous soil of Port-au-Prince, Haiti. Int. J. Environ. Res. Public Health, 10: 5830-5843.

Fuhrer, G.J., 1999. The Quality of Our Nation's Waters: Nutrients and Pesticides. DIANE Publishing, Collingdale, Pennsylvania, ISBN:9780788187858, Pages: 82 .
Gerba, C.P. and C.N. Haas, 1988. Assessment of Risks Associated with Enteric Viruses in Contaminated Drinking Water. In: Chemical and Biological Characterization of Municipal Sludges, Sediments, Dredge Spoils and Drilling Muds, Lichtenberg, J.J., J.A. Winter, C.I. Weber and L. Fradkin (Eds.)., ASTM International, West Conshohocken, Pennsylvania, USA., ISBN:9780803109872, pp: 489-494.

Gove, L., C.M. Cooke, F.A. Nicholson and A.J. Beck, 2001. Movement of water and heavy metals $(\mathrm{Zn}, \mathrm{Cu}, \mathrm{Pb}$ and $\mathrm{Ni}$ ) through sand and sandy loam amended with biosolids under steady-state hydrological conditions. Bioresour. Technol., 78: 171-179.

Graham, L.E. and L.W. Wilcox, 2000. algae. Prentice Hall, Upper Saddle River, New Jersey, USA., ISBN-13: 9780136603337, Pages: 640.

Haddad, R.H., 1977. Hydrogeology of the Safwan area, South of Iraq. Ph.D Thesis, University College London, London, England.

Hadi, R.A.M., 1981. Algal studies of the River USK. Ph.D Thesis, University of Cardiff, Cardiff, Wales.

Hassoune, A.B.E.M., Y. Koulali and D. Hadarbach, 2006. [Effects of domestic and industrial liquid discharges on the quality of groundwater North of the city of Settat (Morocco) (In French)]. Bull. Sci. Inst. Rabat, 28: $61-71$.

Horne, A.J. and C.R. Goldman, 1994. Limnology. 2nd Edn., McGraw-Hill, Inc., New York, USA., ISBN-13: 9780070236738, Pages: 576.

Kena, A.M.M.A., 2001. Study of the quality of sulfuric groundwater in Ninawa Governorate. Master Thesis, University of Mosul, Mosul, Iraq.

Leppi, J.C., C.D. Arp and M.S. Whitman, 2016. Predicting late winter dissolved oxygen levels in arctic lakes using morphology and landscape metrics. Environ. Manage., 57: 463-473.

Ma, W., T. Huang, X. Li, Z. Zhou and Y. Li et al., 2015. The effects of storm runoff on water quality and the coping strategy of a deep canyon-shaped source water reservoir in China. Intl. J. Environ. Res. Pub. Health, 12: 7839-7855.

Parsons, T.R., Y. Maita and C.M. Lalli, 1984. A Manual of Chemical and Biological Methods for Seawater Analysis. Pergamon Press, Oxford, UK.

Prescott, G.W., 1962. algae of the Western Great Lakes Area. 5th Edn., W.C. Brown Company, Winston-Salem, Forsyth County, North Carolina, Pages: 977.

Rasolofomanana, L.V., 2009. Characterization of ranomafana lake-water quality Antsirabe Madagascar. Master Thesis, University of Stavanger, Stavanger, Norway. 
USEPA., 2002. Drinking Water from Household Wells. United States Environmental Protection Agency, Washington, DC., USA.

Wetzel, R.G., 2001. Limnology Lake and River Ecosystems. 3rd Edn., Academic Press, San Diego, ISBN-13: 978-0127447605, Pages: 1066.

White, R.E., J.S. Dyson, R.A. Haigh, W.A. Jury and G. Sposito, 1986. A transfer function model of solute transport through soil: 2. Illustrative applications. Water Resour. Res., 22: 248-254.

Wood, E.D., F.A.J. Armstrong and F.A. Richards, 1967. Determination of nitrate in sea water by cadmium-copper reduction to nitrite. J. Mar. Biol. Assoc. UK., 47: 23-31.
World Health Organization, 2011. Guidelines for Drinking-Water Quality. 4th Edn., IWA Publishing,? London, UK., ISBN: 9781780400303 , Pages: 564.

Xia, J., X. Zhao, Y. Chen, Y. Fang and Z. Zhao, 2016. Responses of water and salt parameters to groundwater levels for soil columns planted with Tamarix chinensis. PloS One, 11: 1-15.

Xie, Y., Y. Wang, V. Singhal and D.E. Giammar, 2010. Effects of $\mathrm{pH}$ and carbonate concentration on dissolution rates of the lead corrosion product $\mathrm{PbO} 2$. Environ. Sci. Technol., 44: 1093-1099. 